SECTION 12. Geology. Anthropology. Archaeology.

Hasanov Elnur Latif oglu

Ph.D. postgraduate

corresponding member of International Academy of Theoretical \& Applied Sciences scholar of Ganja Branch of Azerbaijan National Academy of Sciences,

Ganja, Azerbaijan

el-hasanov@mail.ru

\title{
SOME ETHNO-ANTHROPOLOGIC AND HISTORICAL FEATURES OF CRAFTSMANSHIP HERITAGE OF GANJA FROM ANCIENT TIMES TILL XIX- XX CENTURIES
}

\begin{abstract}
The basic typical craftsmanship branches of Ganja were investigated for the first time from the ethnographic-anthropological point of view in this article. Also, in this scientific work have been researched the main features of these national craftsmanship kinds.
\end{abstract}

Key words: Ganja, ethnographic-anthropological research, handicraft branches, Azerbaijan

Ganja is one of the oldest scientific and cultural centers of the World. This consideration is proved on the basis of indisputable scientific arguments and facts. Development of some local handicraft branches in Ganja historically offered necessary facilities for progress of urban culture. Ganja has more than 4000 years old as an urban center. This consideration is proved on the basis of indisputable scientific arguments and facts [1-3]. Development of some local handicraft branches in Ganja historically offered necessary facilities for progress of urban culture. In traditional production of cloth manufactory trade historically played an important place. This kind of craft that developed on the basis of local raw materials was tied with cotton-growing economy. Since the time of the early Middle Ages, Ganja as Tabriz, Ordubad have been the main center of Azerbaijan in production of cotton cloth. In this ancient city printed cotton and calico fabrics have been widely produced. In traditional cloth productions the main place took the urban mines. In the early 30 s of the XIX century in Ganja there were more than 164 people - weaving. The majority of these artists were weaving. In Ganja, which was the most important center of cloth production were produced different kinds of cotton cloth. Only in the 30s of the XIX century in Ganja were presently working 30 cloth bench $[4 ; 5]$.

In the ancient Ganja during the stage of the Middle Ages the great progress of silkworm was represented by raw silk weaving. For this reason, on the basis of local traditions production of delicate silk textiles from raw silk. From the point of view silkworm breeding development and it's preparing technology there were two main forms of production: socalled raw silk weaving and felt weaving. In this important technological process it has such kind of production stages as cocoon opening, silk initial processing, preparing of raw silk, weaving technology, painting and decoration [3; 7-9].

In III-V centuries, the local craftsmen themselves also became to produce betterdesigned containers. Among the local clay and glass utensils that found in and around Ganja there were big similarity in the form and also in the decoration. All the glass dishes found in and around Ganja are similar with the local clays on decoration of that period.

Glass dishes were containing of Iron, cobalt, magnesium and other elements, that were specific elements for Ganja and its surroundings. The development history of this sphere of craftsmanship can be determined only through archaeological research. Results of archaeological excavations in the territory of Azerbaijan and research show that in the preparation of glass utensils were two technical methods: casting method and the method of blowing. The first of these methods is more ancient, but in the Early Middle Ages and Middle 
Ages were used both of them. Produced glass alloys were transparent colored. By the addition of dusts of various metals in glass alloys people got colored glasses. We can see also to get her with different tinted green glasses also parts of blue, black and pink colored glass dish in sections of IX-X century in Ganja. In IX-X centuries appeared dishes that had handle and spout. Among decorations of that period yellow, white and red beads of round and plain form are met mostly. At the beginning of X-XIII centuries development of production of glass in and around Ganja characterized by improvement from the technology point of view. Archaeological researches show, that outside of the cities in the VIII-IX centuries, also big settlements were established. This is often due to density in cities. The art of Textile materials, that concern to weaving craft, consists of spindle heads and needles. First of all, there have been discovered, that initial ceramic production in Ganja and its surrounding regions are belong to the VIII-VII millennium BC. From the history point of view, these ancient clay vessels, belonging to the Neolithic stage, are differing from the pottery samples of the neighboring ethnic in number characteristics.

These differences are seen in preparing technology, also in the area of external surface decoration. From the construction point of view, samples of pottery, that concern to Antique period, also to the period of Hellenism in Ganja, differed in various forms as pictorial vases, ceramic figures and connected dishes. Pottery dishes, that concern to the first stages of Middle Ages of Ganja, are differing from the ceramic samples of Antique period in two features: on shape and for preparing techniques.

The craftsmanship of carpet-making is one of the important cultural achievements of the Eastern people. In Azerbaijan production of carpets appeared during I millennium BC. In Ganja production of carpets differed with quickly development. Ganja carpets are differing with pile. Thickness indicators of such kind of carpets with comparator small number attract attention ( $25 \times 30)$, composition is more distinct and simple, most of ornamental patterns have geometrical features, in coloring carpet samples were used bright colors, local carpet masters skillfully used buta's amatively patterns [2-6].

Traditional textile of art of silk weaving products has a special place in Ganja. In the city formed two main method of silk treatment: 1. Spinning. 2.Winding. Also, historically the traditional art of saddle-making in Ganja developed in direction of cargo and passenger saddle making. Afterwards military, economic and transportation significance of horse was decrease, the demand for goods of saddle-making also was decrease. In the territory of Azerbaijan the oldest samples of wood treatment were found in the territory of ancient Ganja. Around Ganja area - in the region of Lake Goy-Gol in the IV-III millennium BC have been discovered wooden thicker board, also wooden sugar bowl, that concern to the end of the II millennium $\mathrm{BC}$, found in Mingachevir pitcher grave are material evidences of science thoughts. Have been discovered, that initial ceramic production in Ganja and its surrounding regions are belong to the VIII-VII millennium BC. These rare discover in and around Ganja are known from the archaeological investigations in ancient cultural, art and trade centers of Azerbaijan. The best samples of monuments, that concern to stone treatment are consists of column props, mill and gridding stones. In whole there were founded in and around Ganja a lot of samples, that concern to X century. They are consisting of stone figure, mills and column props. Mill is usually prepared from volcanic, quartz, limestone and basalt. They used for grinding seed, millet, salt and for other aims [6-8]. We meet mostly mill stones, scales and pumice stone in stone treatment. At the same time there were used hewed stones for decorating buildings. In this period there were prepared decorations from precious stone. In traditional production of cloth manufactory trade historically played an important place. This kind of craft that developed on the basis of local raw materials was tied with cotton-growing economy.

Since the time of the early Middle Ages, Ganja has been the main center of Azerbaijan in production of cotton cloth. Also, the prominent geography Strabon lived in $1 \mathrm{BC}$ wrote about natural geographical feature the following: "The soil planted one time can give twice or 
trice harvest, to plow the soil all plains will be full of the rivers and waters. it is well irrigated and in the result of this the meadow will be full of grass. Besides that the air is also fresh. Comparing Ganja with the culture in Egypt and and Babylon dating to the 5 century Strabon noticed that it's the best. Since its foundation and changing its location five times Ganja became one of the most favourable cities and that's why foreign in vaders always wanted to occupy it. To the ancient Turkish tribes name taken from the name of the cityGanja. At different stages of the history of the capital city of Ganja status while maintaining the traditions of the ancient statehood and independence was of great importance. The city is in the province of the Caliphate of the seventh century, the X century and Shaddadis capital of Arran, in the eleventh century Seljuk, was the twelfth and thirteenth centuries residence in Atabays state.

During many centuries in this ancient scientific and cultural center have been formed and developed the handicraft, also architectural styles on the basis of wealthy traditions. Owing to development of centuries-old building and decorative-applied art traditions next to the common features of Arran architectural school, architecture of Ganja guarded some typical, unique skill and architectural characteristics:

Firstly, since the classical and Middle Ages periods in an old cultural and political center-Ganja city, have been built the public and dwelling buildings from the local baked red brick.

In Ganja, first scientist, who has given information about the rich epigraphic, ethnographic, archaeological, numismatic material-cultural patterns, was French researchers Dubua de Monpere. In 1834 on the way to Tiflis (Tbilisi) he came to Helenendorf (now Goygol) and found different black-colored ceramic plates and bronze patterns (objects), which showed, that an ancient city culture formed here. Also, many archaeological wares and material patterns, that have found by Zare, Morgan, Virkhov in that period, are reserved in Moscow, Petersburg, Drezden and in other European museums. V. Belk, who worked in Dashkesen, Gedabei copper minds, found here more than 300 monuments, which proved the ancient city culture of Ganja. Main parts of these items are reserved in Hamburg and Munich museums.

E. Resler, who was the teacher in Ganja (Yelizavetpol) province in 1892-1903 years, on the basis of his researches around of Ganjachai (Ganja river) has found many materials, connected with the ancient history and culture of this city. Some parts of his material patterns are now reserved in Moscow and Saint-Petersburg museums. In 1896 A. Ivanovsky with the request of Moscow Archaeological Society has been sent to the province of Yelizavetpol for archaeological excavations. Here he has found the old city cemetery with 72 stone boxes graves and sent those materials to Moscow. Now these materials are kept in the Moscow History Museum.

In 1903-1914 years B. Rozendorph, who was working pharmacists in Helenendorf carried out scientific-researches throughout in the territory of Ganjachai, discovered extremely valuable historical materials in Ganjachai valley Helenendorf and Chovdar villages, also graves of the ancient stone boxes, which reflected the old urban culture. Information about his researches was published in St. Petersburg in 1906, on "Reports of the Imperial Archaeological Commission". Mining engineer B.Sults, who worked in the region of Ganjachai in 1898-1903, an officer in the military service in Yelizavetpol in 1905 V.A. Skinder, mining engineer F. Lass in 1908, E.P. Paritsenmayer in 1910, and many foreign researchers found in area Ganjachai the existence of extremely valuable historical materials. Some examples of them are kept in the museum of Berlin. Yaakov Hummel, who had German nationality and worked in Helenendorf (Goygol) in the secondary school biology teacher with the help of the student circle of the school during the archaeological researches on the right and left banks of Ganjachai has found valuable materials, that concern to the 
Bronze and Iron age. The value of found materials was so great, that here has been created in Regional Museum of Helenendorf in 1927.

In Ganja and its regions during centuries ceramic trade has following kinds: 1. Building ceramic materials. 2. Unglazed ceramic products. 3. Glazed ceramic products [3-7].

Historically the traditional art of saddle-making in Ganja developed in direction of cargo and passenger saddle making. The art of saddle-making within the local saddle-types and their components were determined on a specialization. The production of cargo or packsaddle a rule was engaged by pack-saddle maker. For this reason, in most cases, the profession was called trade of pack-saddle maker. Afterwards military, economic and transportation significance of hoarse was decrease, the demand for goods of saddle-making also was decrease.

The reason of primitive saddle-making decreasing was wide sale of cheaper factory products. Samples of glass decorations, of BC, we met in the patterns of Ganja and surround territory. In these areas, the first centuries BC were found in samples of the glass plate. The majority of containers and the analysis based on graphical elements of the Roman scholars came to the opinion that the samples of the same scale as the Roman Empire through trade. There are more than 2000 beads in complex materials. Colored beads have prepared of different types products. Mostly distinguish beads that prepared from blue green and grey paste. A group of beads made of bone and antimony Historically the traditional art of saddlemaking in Ganja developed in direction of cargo and passenger saddle making. The art of saddle-making within the local saddle-types and their components were determined on a specialization. The production of cargo or pack-saddle a rule was engaged by pack-saddle maker.

For this reason, in most cases, the profession was called trade of pack-saddle maker. Afterwards military, economic and transportation significance of hoarse was decrease, the demand for goods of saddle-making also was decrease. The reason of primitive saddlemaking decreasing was wide sale of cheaper factory products. Samples of glass decorations, of $\mathrm{BC}$, we met in the patterns of Ganja and surround territory. In these areas, the first centuries BC were found in samples of the glass plate. The majority of containers and the analysis based on graphical elements of the Roman scholars came to the opinion that the samples of the same scale as the Roman Empire through trade. There are more than 2000 beads in complex materials. Colored beads have prepared of different types products. Mostly distinguish beads that prepared from blue green and grey paste. A group of beads made of bone and antimony Historically the traditional art of saddle-making in Ganja developed in direction of cargo and passenger saddle making. The art of saddle-making within the local saddle-types and their components were determined on a specialization.

The production of cargo or pack-saddle a rule was engaged by pack-saddle maker. For this reason, in most cases, the profession was called trade of pack-saddle maker. Afterwards military, economic and transportation significance of hoarse was decrease, the demand for goods of saddle-making also was decrease. The reason of primitive saddle-making decreasing was wide sale of cheaper factory products. Samples of glass decorations, of BC, we met in the patterns of Ganja and surround territory. In these areas, the first centuries BC were found in samples of the glass plate. The majority of containers and the analysis based on graphical elements of the Roman scholars came to the opinion that the samples of the same scale as the Roman Empire through trade. There are more than 2000 beads in complex materials. Colored beads have prepared of different types products. Mostly distinguish beads that prepared from blue green and grey paste. A group of beads made of bone and antimony Historically the traditional art of saddle-making in Ganja developed in direction of cargo and passenger saddle making. The art of saddle-making within the local saddle-types and their components were determined on a specialization. The production of cargo or pack-saddle a rule was engaged by pack-saddle maker. For this reason, in most cases, the profession was called trade of pack- 
saddle maker. Afterwards military, economic and transportation significance of hoarse was decrease, the demand for goods of saddle-making also was decrease. The reason of primitive saddle-making decreasing was wide sale of cheaper factory products. In these areas, the first centuries $\mathrm{BC}$ were found in samples of the glass plate.

The majority of containers and the analysis based on graphical elements of the Roman scholars came to the opinion that the samples of the same scale as the Roman Empire through trade. There are more than 2000 beads in complex materials. Colored beads have prepared of different types products. Mostly distinguish beads that prepared from blue green and grey paste. A group of beads made of bone and antimony [12-15].

At the end we can say that, during many centuries in this ancient cultural and scientific center developed different branches of craftsmanship.

\section{References:}

1. Ohmədov F.M. Gəncə şəhərinin yerdəyişmələri / Gəncə tarixinin aktual problemləri. II elmi-praktik konfransin materialları. Gəncə: Elm, 2010, s. 53-63

2. Guliyeva N.M., Hasanov E.L. About ethnographic-archaeological research of some handicraft branches of Ganja during XIX - XX centuries / Progressive scientific explorations - 2012: Proceedings of the 8th International scientific-practical conference. Prague: Publishing House - Education and Science s.r.o., Prague, (Czech Republic), 2012, 73-75

3. Azərbaycan etnoqrafiyası: 3 cilddə, I c., Bak1: Şərq-Qərb, 2007, 544 s.

4. Кавказский календарь на 1854 г. Тифлис, 1853 , с. 338-341

5. Həsənov E.L. Gəncə İmamzadə türbəsi (tarixi - etnoqrafik tədqiqat). Bak1: Elm və təhsil, 2012, $268 \mathrm{~s}$.

6. Ergenekon Cavidan. Tempe keçe sanatında geleneksel süsleme üsulları ve günümüzde bu saneye yönelik yeni yaklaşımlar / Azərbaycan xalçası və xalq tətbiqi sənəti mövzusunda III Beynəlxalq simpoziumun materialları. Bak1: Elm, 2005, s. 45-46

7. Häsänov E.L. Die Gändschänischen teppiche von XIX - XX Jahrhundert als geschichtliche - ethnographische quelle / European Science and Technology (Die Europäische Wissenschaft und die Technologien): $2^{\text {nd }}$ International scientific conference. Bildungszentrum Rdk e. V. Wiesbaden, (Germany) 2012, p. 26-27

8. Azərbaycan tarixi üzrə qaynaqlar. Bakı:Azərbaycan Universiteti nəşriyyat1, 1989,328s.

9. Guliyeva N.M., Hasanov E.L. New ethnographic approach to the research of main decorative - applied arts of Ganja of the XIX - XX centuries / International scientific conference - Achievements in science: new views, problems, innovations. Lodz, (Poland) 2012, p. 56-58

10. The dawn of Art. Leningrad: Aurora Art Publishers, 1974, 196 p.

11. Guliyeva N.M., Hasanov E.L. Investigation of basic decorative-applied arts of Ganja on the basis of some innovative arguments and technologies / Science and Society: Proceedings of the 3rd International scientific-practical conference. London (Great Britain), 2013, p. 281-291

12. Алиева А.С. Ворсовые ковры Азербайджана XIX - нач. XX веков. Баку: Элм, 1973 , c. $21-25$

13. Burton-Brown T. Excavations in Azerbaijan, 1948. London, 1951, 250 p.

14. Hasanov E.L. Some innovation historic-ethnographical arguments about development of craftsmanship in Ganja / Science, Technology and Higher education: Proceedings of the 1st International scientific - practical conference. Westwood: Publishing office Accent Graphics communications, Westwood, (Canada), 2012, p. 485-491

15. Hasanov E.L. About fundamental studies on local cultural traditions of Ganja // European journal of Natural History (Fundamental researches: Proceedings of International scientific conference. - Jordan, Aqaba), 2013, № 3, p. 65-68 